\title{
The role of endowments in the realization of peace and human rights
}

\section{El papel de las dotaciones en la realización de la paz y los derechos humanos}

\author{
Jafar Sabbaghian Deloui \\ $\mathrm{PhD}$ student in International Law, Damghan Branch, Islamic Azad University, Damghan, Iran
} ORCID: https://orcid.org/0000-0003-2327-9588

\section{Ali Pourqasab Amiri}

Assistant Professor, Department of International Law, Damghan Branch, Islamic Azad

University,Damghan, Iran

ORCID: https://orcid.org/0000-0003-4702-6497

\section{Alireza Jahangiri}

Assistant Professor, Department of International Law, Damghan Branch, Islamic Azad

University, Damghan, Iran

ORCID: https://orcid.org/0000-0003-1971-1016

\section{Ahmad Reza Behniafar}

Assistant Professor, Department of Islamic History, Damghan Branch, Islamic Azad University, Damghan, Iran

ORCID: https://orcid.org/0000-0001-7109-3687

*Correspondence

Email: aliamiri20@yahoo.com
Cite as:

Sabbaghian Deloui, J., Amiri, A., Jahangiri, A. \& Behniafar, A.R (2021). The role of endowments in the realization of peace and human rights. Propósitos y Representaciones, 9 (SPE1), e890. Doi: http://dx.doi.org/10.20511/pyr2021.v9nSPE1.890 


\section{Summary}

The purpose of this article is to examine the role of endowments in the realization of peace and human rights. Endowment means that the property of imprisonment and its benefits should be placed in the way of God. The meaning of endowment is the permanent benefit of the endowment against the property of the endowment, and for this reason it has been called endowment, and among the benefits is the transfer of interests in the way of God and social charity. So far, several researches have been done in the field of endowments but, the study of the functions of the endowment and the role of its endowments, especially in the field of peace and human rights, has not received much attention. The basic question that has been raised and examined in this regard is that what role does endowment play in achieving peace and the standards of the third generation of human rights? The present article is a descriptive-analytical and examines the question using the library method. The results of this article indicate that positive peace focuses on health, disease and the fight against disease, poverty, social and economic inequalities, and the realization of social justice and at the same time, the components of the third generation of human rights are trying to realize such things as the right to development, the right to education and the right to occupation that due to its functions, endowment plays an important role in providing the mentioned items. In conclusion, it can be said that endowment is effective in strengthening and promoting positive peace and the components of the third generation of human rights.

Keywords: endowment, endowments, peace, human rights

\section{Resumen}

El propósito de este artículo es examinar el papel de las dotaciones en la realización de la paz y los derechos humanos. La investidura significa que la propiedad del encarcelamiento y sus beneficios deben ponerse en el camino de Dios. El significado de la investidura es el beneficio permanente de la investidura contra la propiedad de la investidura, por eso se le ha llamado investidura, y entre los beneficios está la transferencia de intereses en el camino de Dios y la caridad social. Hasta ahora, se han realizado varias investigaciones en el campo de las dotaciones, pero el estudio de las funciones de la dotación y el papel de sus dotaciones, especialmente en el campo de la paz y los derechos humanos, no ha recibido mucha atención. La pregunta básica que se ha planteado y examinado a este respecto es ¿qué papel juega la dotación en el logro de la paz y los estándares de la tercera generación de derechos humanos? El presente artículo es de tipo descriptivo-analítico y examina la cuestión utilizando el método de biblioteca. Los resultados de este artículo indican que la paz positiva se centra en la salud, la enfermedad y la lucha contra la enfermedad, la pobreza, las desigualdades sociales y económicas y la realización de la justicia social y, al mismo tiempo, los componentes de la tercera generación de derechos humanos están tratando para hacer realidad aspectos tales como el derecho al desarrollo, el derecho a la educación y el derecho a la ocupación, que por sus funciones, la dotación juega un papel importante en la provisión de los artículos mencionados. En conclusión, se puede decir que la dotación es eficaz para fortalecer y promover la paz positiva y los componentes de la tercera generación de derechos humanos.

Palabras clave: investidura, donaciones, paz, derechos humanos

\section{Introduction}

Endowment or Trust is one of the most obvious and long-standing valuable heritages of human culture and civilization that has been considered in all human societies since the beginning of Islam and in spite of the problems, it has left very valuable and effective works in various 
cultural, scientific, social and economic fields. Due to the importance of annual endowments and over time, people around the world dedicate their private property for personal purposes.

The most important social characteristics of the endowment can be summarized as follows: 1One of the most obvious social features of the endowment system is its non-class nature. This means that the tradition of endowment is always available to all sections of society and is not and is not exclusive to a particular class. 2- The endowment system is the basic framework of mutual responsibilities and social solidarity between the rich and the needy. 3 - The endowment system has been and is one of the mechanisms for achieving social justice and peaceful means for redistributing income without any coercion and intervention of the ruling power. 4Endowment has a tangible role in providing welfare services (especially in occasions and events and important personal and family decisions such as marriage, employment, education, holding mourning ceremonies, etc.). 5- Endowment in support of the family unit is the cornerstone of society and maintaining its cohesion and integrity through financial and logistical support, as well as protecting the rights of the weak and sick, families and those with less physical and mental disabilities, play an important role. 6. Endowment is to provide a basic framework for people's participation in social affairs that is, it makes a person's decision for charities (such as a hospital school). (Mohtadin, 2007: 19) Meanwhile, the discussion of peace and human rights is one of the important issues that has become increasingly important. In this article, the focus on peace is in the positive sense that it is closely related to the third generation of human rights standards. In accordance with positive world peace, they must work for world peace in the interests of development, human rights, human security and justice; and deal with disease, poverty, social and economic inequalities, discrimination, illiteracy and the damage to the natural and social environment, so that all human beings can profited by the facilities of a normal and normal life, together and for each other, have a transcendent life and experience empathy and fellowship. (Saed, 2010: 24). In addition, the third generation of human rights has been discussed in recent decades. The rights mentioned in some UN resolutions include the initial planning of a number of treaties and in the African Charter on Human and Peoples' Rights. Stephen Marquez considers the new generation of human rights to include the right to development, peace, and the right to education (United Nation, 1995: 30). The main question that is raised and examined in this article is that what is the role of endowment in achieving peace and human rights? In order to review and answer the question, first the theoretical framework of the article should be reviewed and in the following, the role of endowment in the realization of peace and then the role of endowment in the realization of the third generation of human rights are examined.

\section{Theoretical framework}

From the point of view of functionalist sociologists, social life is not a random event because society and its related processes have a system and model and social behaviors also have regular and specific patterns and have a variety of functions that may be positive or negative, this theory states: in normal conditions, all elements and systems of society such as schools, family and government are compatible and inclined and in this way, each element helps to maintain overall stability, with this definition, endowment can be considered to have various functions, which are: A: Doing development. B: Psychological and emotional satisfaction of the endowment or endowments. C: Helping the poor and needy. D: Performing religious ceremonies is the endowment of a religious behavior. Religion has these various functions. Religion can contribute to social solidarity. Give meaning to social life and social control are other religious functions. Endowment has some of these functions. Taxes, Khums, Zakat and Endowment each have similarities and that is part of the property or assets of individuals is spent on social affairs but endowment is an voluntary behavior that the endowment can have full authority to perform, but khums, zakat and taxes are mandatory.

At the same time, the militant view believes that society is composed of tension, social processes, conflict, competition and social inequality. They accept the assumption that societies are constantly evolving and that conflict is their constant characteristic. They believe that there 
are two groups in society; Rich and poor. Phenomena such as endowment such as khums and zakat can lead social inequalities towards equations and equality, economic and social justice. Endowment is an important step towards the implementation of economic and social justice. In history, we see many examples that the emergence of many heroes and politicians in the social arena, has led to the presence of endowment and leading society to justice. The view of structuralists in explaining the endowment can be effective in analyzing the subject of the present article. In the 1920s, it was proposed by the British anthropologist Radcliffe Brown. Structuralists talk about the construction of society. Construction means a set of interconnected components that are related. If we examine the endowment from this point of view, we must study its components, which are the organization and administration of endowments. Endowment is an organization that adapts its efficiency to administrative and human needs and this attitude can study and evaluate the problems of the endowment organization and its relationship with the institution, social organizations and how to manage endowment sites to solve existing problems. (Mohtadin, 2007: 58). Endowment is a social phenomenon that is related to the geographical environment and value system and cultural norms of a society. Endowment can affect the social system and political and cultural behaviors and help solve society's problems also be influenced by social institutions and cultural agents. For this reason, those involved in political and social issues can examine the endowment from their point of view and explore the theoretical and define operational theory in accordance with social norms.

\section{The role of endowments in achieving world peace}

In this section examines the role of endowments in achieving world peace.

\section{The nature of peace (positive peace)}

Peace is a word that generally refers to the absence of aggression, violence or hostility, but it also encompasses a broader concept that includes health, newly improved interpersonal or international relations, security in matters of social or economic welfare, recognition of equality and fairness in political relations and in world affairs. Peace time is a state without war or conflict. In other words, the understanding of the nature of peace becomes clear when it is lost or lack. But in the face of any insecurity, socio-economic injustice, political fundamentalism, religion and extremist nationalism can all lead to a breach of peace (Amininia, 2010: 156). In general, peace has two different meanings. Negative peace is informed by the absence of organized violence and roughness between different nations, races and ethnicities. (Vali, 1991: 236) In the legal and political studies, negative peace is essentially the absence or denial of war, not other acts of subversion. According being said, we do not mean negative peace. Because this peace only includes the absence of war and does not pay attention to other factors that threaten peace and security. But positive peace, which requires not only the absence of war, violence and roughness, but also cooperation and balance between nations (Vali, previous source, p. 336). In the contemporary and broader reading of positive peace, "war" has become "conflict", to cover the use of force as well as non-coercive but unfriendly methods in the social relations of the real and legal members of any organized national or international complex. For this reason, peace has transcended attitudes about limiting, controlling, or prohibiting "war" and encompassing "conflict" at all personal and geopolitical levels. In other words, war has taken on a traditional form and taken on new forms. The war of nations is a new face of war beyond intergovernmental conflicts (Cortight, 2008: 5). The issue that considers peace in human life as a direct function of the absence of some conditions of negative components and the existence of some requirements of positive components. Such an approach is a comprehensive and accepted approach in contemporary peace studies that, in addition to its philosophical and social foundations, in addition to its philosophical and social foundations, it also has a convincing consistency in international legal norms and rates.

\section{The role of endowment in achieving peace (positive)}

Endowment is the best and most effective means of Islamic social welfare. It is one of the 
advantages of Islamic law, which encourages Muslims to social welfare, encourages them to give alms in good ways and to help the poor. The texts of the Holy Quran and the hadiths of the Prophet emphasize this. These religious texts have been an important motivation for Muslims to give alms in the past and dedicate their property in various ways of goodness and improvement (Sadeghi Goldar, 2006, 192). There are no specific verses in the Holy Qur'an about endowment, but what is done in doing good deeds is indicative of these deeds. Some Islamic scholars have quoted some blessed verses in this way: Including the verse: "Give to the relatives and the orphans and the helpless and the helpless in the way of beggars and spend in the way of freeing the slaves and performs prayers and pays zakat, have been faithful to their covenant, when they make a pact against poverty and be patient in battle, these are the ones who are truthful and truly pious". Every civilization has its own characteristics and signs, which distinguish it from other civilizations. Most of these signs and properties come from the basic principles and goals of that civilization. Islamic civilization among other civilizations has the privilege of the principle of social commitment among members of society, which has been adapted to a wide range at different times. According to this principle, Muslims had the shape of a body, the suffering of one person is considered the suffering of the whole society. Therefore, Muslims try to share the money that God has given them to the travelers and the needy. We do not find this commitment and sense of brotherhood and fellowship in other religions. The system of endowment was not common in the time of ignorance. The Holy Prophet (PBUH) encouraged the companions of the Holy Prophet (PBUH) to meet the needs of the poor with this type of charity. Westerners recognized endowment after becoming acquainted with Islamic civilization. They established institutions such as (Angelosconia) based on endowment in Islamic jurisprudence. But they aimed at this action only for the benefit of the world, which had nothing to do with the Hereafter and its reward. The most famous endowment in the United States is the John O'Sullivan Endowment (Shah Hosseini, 2009: 92-96).

\section{The role of endowments in the development of the economic foundations of world peace}

When we talk about the effect of endowment on economic independence and growth and development, it never means that endowment alone can cover all different dimensions and angles of a nation's economy. So that the country's economy no longer needs financial resources, but it means that the endowment, as a huge financial asset, can play a constructive and significant role in this regard. Nor does it mean that, contrary to the goals of the endowment, the endowment income is one of its main uses that is stated in the endowment letters, do deviate and use and consume them in the way of achieving economic independence and growth and development. The truth is that the huge capitals of the endowment, like other capitals, can be placed in the production and service activities during the production and service activities, observing all aspects of the endowment, the sharia standards of the endowment goals, and guide them from a state of stagnation to a state of mobility and dynamism, thereby contributing significantly to the country's growth, development and economic (and political) independence; Also increase the endowment funds, which is certainly in line with the goals and endowments.

But it may be said that endowment means imprisonment and confiscated capital cannot be used for economic activities. In response, it can be said that the word imprisonment, which is mentioned in the definition of endowment (cf. Mohaghegh Hali, 1989: 255; Fakhr alMuhaqiqin, 2009, vol. 2: 377) It never means confiscating the capital and property of the endowment from being in the path of production and services (of course, by observing the rules, goals and endowments). Imprisonment here means prohibiting and preventing the transfer of competition and endowment capital to another and this never means confiscating endowed property from economic activities. In jurisprudential discussions and in most endowment letters, it is stated that in the first stage, it is necessary for the income of the endowment property to be spent on repairs and correction of the competitor in order to remain safe and secure and to be able to have more income, that means, increasing the income of endowment capital (by 
observing the criteria), which is to the satisfaction of the legislator and also to achieve the goals of the endowment.

In Islam, worship, politics, and economics are intertwined, and economic prosperity is guaranteed by the establishment of programs such as khums, zakat, almsgiving, gifts, and endowments. Using the income of endowments for road construction, creating public places, building bridges, setting up production factories, youth employment, feeding the poor, providing cheap housing for the youth, investing in development, industrial and agricultural projects, reducing prices, increasing production ${ }_{s}$ it shows the effect of endowment in solving economic problems. (Salimifar, 1991: 106).

Most of the uses that far-sighted and charitable endowments have made throughout the history of endowment relate to public welfare, poverty alleviation, and social justice. If we take a brief look at the history of endowments and the content of endowment letters, we will find that wellmeaning and far-sighted endowments have considered all angles and aspects of needs. The intention of the Commanders of the Faithful (pbuh) to dedicate the water farms of Nizar, Baghibgheh, Chah Baghibgheh, etc. for the poor and the travelers, as well as other endowments of the Imams (AS) (Aminian Modarres, 2003: 18) for the poor and public use, it is a symbol of poverty alleviation in Islam. Endowments throughout history have always met the essential needs of the underprivileged, such as orphans, widows, the elderly, the displaced, travelers, and the bereaved.

\section{The role of endowments in the development of cultural foundations of world peace}

The history of endowments such as schools, research centers, universities and libraries shows the power of cultural endowment of endowment and endowment service to religion and knowledge. From the beginning of Islam until now, the educational and cultural function of endowment has been one of its most prominent functions in Islamic societies. Providing a suitable platform for education and research for students and scholars is one of the factors of expansion in the Islamic world and Endowment as a source of funding for scientific centers and public support has played a role in this regard. The financing of some schools and the living expenses of some religious scholars and researchers and the provision of their educational facilities on a relative and partial basis from the income of the endowments is an undeniable thing. (Bakai, 1998: 84).

The most important function of endowment in the Islamic society from the distant past until now is the educational and cultural function. The educational and cultural dimensions of endowment are very wide in Islamic societies. Endowment, as a continuous source of funding for scientific centers, has had popular support and many schools and scientific centers in the Islamic world have been created and expanded through endowments and many great scholars have been able to achieve high scientific degrees by using the income of endowments. By financially strengthening Islamic schools through endowments, these schools were able to influence the culture of the European education system. Endowment is the guardian of the dissemination of Islamic knowledge. Using the endowment income to build mosques, universities, student dormitories, establish public libraries, hold the World Hajj Congress, mourning ceremonies of the Imams (AS), Holy Quran recitation competitions in the international arena and... is one of the cultural and educational functions of endowment. Through the endowment channel, Muslims have been able to introduce their best masterpieces to the world through the endowment religious schools. Their science and knowledge has been spread and popularized through endowments (Taghizadeh, 2008: 166-165).

The subject of endowment can be the basis of many works of art such as stories, TV series and movies to gradually spread this culture, individualistic thinking, limited and confined, and thinking about the fate and life of others. (Ibid., P. 171)

The role of the endowment in promoting the cultural and intellectual development movement 
can be as follows:

1- Support for cultural and religious institutions that are close to the people.

2- Renovation and invitation tools (advertising) and preparing them for meeting future needs and guiding cultural and artistic leaders and develop systems that train preachers.

3- Support of scientific research institutes and centers of intellectual studies.

4- Approval and acceptance of scientific activities that use new methods of futurism (science of the future) and uses them in the development of new methods of jihad (Mostofi, 1998: 4).

\section{The role of endowments in the development of the social foundations of world peace}

The good tradition of endowment is one of the clear examples of humanity that using the teachings of the prophets, man has founded it for a long time and has deposited it in the scene of social life. The spirit of social cooperation and precedence in charity is embodied in the institution of endowment and the practice of endowment is forever sealed. In endowment, the two dimensions of human self-friendship and altruism come to the fore. One of the arts of Islam in order to further influence words in human beings is to use selfishness which is mentioned in various verses addressed to human beings. In endowment, he also uses the dimension of human self-friendship and considers membership in this institution as a way which the name of man and the ownership of his property and assets are guaranteed forever and in cases which it is intended, revenues are used (Journal of Problems, p. 20:26).

Many social services in the past were provided through endowments, caravanserais, ligaments, orphanages, etc. were places that were in great need of the traditional society, and the Endowments took action in view of this category of social needs, supporting orphaned children Creating an educational complex in deprived areas of the country, etc. is one of the most important social functions of poverty in society.

The most prominent manifestations of endowment in social development are:

1- Necessary support for research and studies related to social aspects in Islamic thought.

2- Paying attention to some social classes, such as family, women, youth, children, and people with special needs.

3- Endowment can play an important role in controlling and solving some problems in the field of non-Islamic values.

4- Preparing an appropriate organizational and financial framework for the development of the local community.

5- Endowment is a valuable experience in the field of social integration and strength. An experience that needs to be updated and adapted to the times.

6- Endowment can be effective in normalizing the important role of non-Muslim minorities living in Islamic societies (Eghbali, pp. 130, 68).

To create a reasonable balance in cultural development, a balance must be preserved between the dynamic and static dimensions of cultural movement, that is, the balance between variables and constants in the culture of society. Cultural tradition in the traditional aesthetic concept may prohibit the movement of an individual or a community, unless this tradition has been established through the study of contemporary ambiguous problems, that is, through a dynamic perception. 
Endowment, as one of the institutions of civil society, paves the way for the development of institutions independent of the government and in this way, it can increase the coefficient of social security. It means; first, the various individuals who benefit from the endowment within the legal framework, they will feel relatively more secure in various fields, especially in the economic field. Second, the endowment can be used in various national projects such as the realization of scientific, academic, research and cultural programs, and in this way, the success rate will also improve the criteria related to the national security of the country. In addition, with the role of more and more civil institutions, the government institution will have more opportunities and power to spend its time and energy on specialized and case studies in the country. Therefore, endowment is closely related to security, which causes the expansion and promotion of the institution of endowment and the promotion of civil institutions. Institutions outside the power structure can provide security in both individual and national categories. Obviously, the expansion and promotion of the endowment institution is not the reason for its success. In other words, the condition is necessary but not enough. Optimum management of endowment affairs also completes the issue and can be very effective in the success of this institution of civil society. At the same time, the endowment provides the necessary foundations for the realization of social justice and equal opportunities if the culture of endowment spreads in the communities, it can well help in matters related to the elimination of discrimination and inequality or economic. Of course, this is not the final solution, but it can help solve part of the problem.

Social justice, security and endowment are three interrelated elements; security is born of social justice, Endowment can help promote social justice with proper management and planning. Social justice provides equal opportunities in society and can meet many different social challenges.

Security has two internal and external dimensions that are interrelated. In the internal dimension, overt and covert threats create insecurity within borders, such as political threats (insurgency, separatism, etc.), economic and military crises (civil war, etc.) and social unrest, each of which oppresses the people. Externally, security can be threatened by political, military and economic issues (economic sanctions, tariffs, etc.)

If the endowment spreads in the society, it can solve many social problems and have a tremendous effect on eradicating poverty and deprivation and avoid extreme class differences that by the nature of these, through the expansion of social justice based on merit, they provide the means to compose the hearts of Muslims towards each other "(Salimifar, 1991: 8). If wealth is accumulated in the hands of some, on the other hand, others will be deprived and the gap between sections of society, on the other hand, provides the background for theft, bribery, prostitution, greed, arrogance, and self-aggrandizement and neglect for the wealthy.

\section{The role of endowments in the realization of human rights}

This section examines the role of endowments in the realization of human rights.

\section{The role of endowments in the right to education}

The right to education is mentioned in various international and regional documents and almost all of them have provided specific criteria and guidelines for this right ;among these, the International Covenant on Economic, Social and Cultural Rights has a special place. Article 31 of the Covenant recognizes the right of everyone to free education and declares that the goal of education should be to advance human dignity and, ultimately, international peace. In the second paragraph, this article describes the different courses and requirements related to each level and third paragraph talks about educational freedom, which is a part of parents' freedom in choosing a school for their children and other part discusses the freedom of individuals to establish and run educational institutions. The second paragraph of Part A of Article 31 emphasizes that primary education must be compulsory and available to the public free of 
charge.

One of the types of endowments is educational and cultural facilities that by creating and financing them, it helps to raise the level of knowledge and development of the society. Such endowments in the Qajar period have been manifested mainly in the teaching of religious sciences and since the end of this period and in the Pahlavi period, in addition to the teaching of modern sciences. Attention to intellectual sciences was introduced in a new style after the establishment of this school and sending students to Europe and more communication and interactions with the West at the school level.

Accordingly, in most of the Qajar period, if people wanted to study in intellectual and modern sciences such as arithmetic, geometry, geography, chemistry, etc., they could hardly prepare the relevant books in Iran (Masoudi, 2008: 3) and they had to go to Europe to continue their education. However, students sent to Europe could not have much success in European academy due to structural instability and some of them were trained experimentally (Hashemian, 2000) and construction of the Dar al-Fonun school, the Diamond Industrial Complex, and the Industrial Complex, as well as foreign schools, did not make much difference in reducing education from the level of libraries and seminaries to education at other levels. Of course, apart from the factor of religion, other factors such as people's lack of attention to productive and technical jobs and the dominance of the commercial economy can have been effective in this regard. But this trend changed from $1898 \mathrm{AH}$ onwards and continued in the Pahlavi period.

Endowment letters, in addition to expressing how to use the endowment income, also provide important points about the use and system of school administration and curriculum which helps to identify training centers and how they operate.

Therefore, endowment letters can be considered as a statute that, by setting conditions, encourages talented students and punishes stupid students (Riahi, 2012: 119).

The interesting thing about these endowment letters is that, apart from the above, the founders of the schools have also commented on the content of the courses. For example, in the endowment letter of Maryam Begum School, it is stated: "... And there should be books of sciences and all that is, the sciences of doubt and suspicion, which are known and popular as rational sciences and wisdom, such as healing, signs, wisdom of the eyes, explanation of guidance, and the like should not be read in doubt about entering the preliminaries of religious sciences (Spanta, 1927: 245).

In the case of most schools, it is said that there was no time limit for completing their education, but by studying the endowment letters, it can be seen that some endowments have paid attention to this important point and they have set a time condition for staying in school (Ibid., P. 247). The situation was similar in the West, with the church and the clergy in charge of education and training and even those who became clergymen in clerical garb, it was possible for them to be paid for their livelihood as secretaries and aristocracy and large landowners. Stendhal's book Red and Black describes the social situation of the time and the occupations of the clergy in the form of a time: "When the waves of ethnic migration subsided in the sixth century, there were several non-church schools in Italy. The rest of the schools were mostly devoted to training new monks and priests. For some time (500 to $800 \mathrm{AD}$ ) the church turned its full attention to spiritual education and he never considered the transmission of secular information as one of his duties but it was at Charlemagne's insistence that cathedrals, monasteries, local churches and nunneries opened schools for the general education of boys and girls. In the beginning, the monasteries carried almost all of these burdens and there was usually a secularizer (inner school) in the monastery whose job was to teach religion and train novices to become priests and an exterior school that ostensibly paid for boys' education." (Will Durant, B. Ta, J 4: 613) Education, which is in any case one of the foundations of human civilization, it has been Christianized in the West until recently ruled by the clergy. Even the universities were established with the budget of the church and the people and continued to operate. 


\section{The role of endowments in realizing the right to employment}

In the International Covenant on Economic, Social and Cultural Rights, the right to employment was considered in three articles, Articles 6,7 and 8. The right to employment as recognized in Article 23 of the Universal Declaration of Human Rights and article 6 also includes the Second Covenant. It is also supported in many other texts and documents, such as the Convention on the Elimination of All Forms of discrimination against women and the convention on the rights of persons with disabilities. The good tradition of endowment is one of the most general and oldest phenomena of participation, cooperation and empathy between communities that this participation and empathy of the people through endowment, causes the organization of the environment, the creation of urban spaces and the creation of public welfare.

"The endowment system has not only led to the construction and creation of many valuable spaces and elements in cities, rather, the spiritual connection and close connection of the endowment with religious affairs has caused the permanence and stability of the endowment urban spaces over time. Also, the eternal, permanent and non-marketable nature and transferability of endowments and the use of their competitive resources in the way of charity and for the sake of the works and interests of the Muslim community that Many of them have resisted the events and misfortunes of history and reached the present." (Masavat, Baba Amiri, Farhadi, 2016: 9).

The tradition of endowment provides the basic needs of the people such as job creation, construction of bridges, factories, orphanages, various things for the beauty of the urban space and leads to the realization of social welfare in society.

Sanatoriums, orphanages, begging houses, water reservoirs, planting trees and fruit trees, for the beauty of the city and the use of passers-by, financing girls' marriages and other charitable activities, such as supporting divorced women in the form of shelters, public baths, stairs, city fences, cemeteries, are among the items of public goods that have been funded by endowments in the past. (2007, Karim)

Another blessing of the endowment and its valuable consequences is job creation or maintaining and stabilizing various jobs. This important effect is made quite clear by a careful look at the text of the endowment letters. It is therefore very appropriate that those involved in the employment crisis; To a scientific and new approach to the element of endowment; Part of the ominous effects of reducing unemployment and provide more healthy and productive jobs. (Ayatollah, 2004: 351-345).

Endowments can also help in creating employment. According to the tradition of endowment, many groups of different classes of society are associated with endowments in some way or directly and indirectly supervise endowment matters. Of course, in the past this connection was more and now direct communication is less. According to surveys, the number of people employed in endowed institutions and properties, can be very high compared to those directly employed by the government. In this way, in addition to meeting their needs over time, by creating more employment, it also increases more national product, which is one of the reasons for the economic prosperity of the society. (Salimifar, 1991: 167-166). It is worth mentioning that with the help of the endowment institution, we are able to develop schools and scientific centers that leads to the employment of experienced and compassionate professors which the result is to give many scholars and thinkers to the Islamic society. Therefore, the expansion of the endowment of money is an important factor in reducing the level of poverty and economic and cultural prosperity in society.

\section{The role of endowments in realizing the right to development}

The third generation of human rights, without defining all their instances, seeks to fulfill the prerequisites of a desirable life in which human beings feel prosperity and happiness. Due to the changes and transformations in the aspects of 
human life, the third generation of human rights is also following in the footsteps of these changes. (Molaei, 2002: 137). The right to development can be considered as one of the examples of rights, solidarity, or the third generation of human rights that are examined in this article. The concept of "right to development" was first introduced in 1972. In 1981, the working group of the United Nations was convinced that these issues should be organized and systematized and therefore, a new working group of government experts on the right to development should be established. Five years after the formation of this new group, the United Nations adopted a Declaration on the Right to Development and gave a mission to the said commission to follow the ways to implement the resolution. In 1993, the Human Rights Commission appointed another working group to define the concept of development and suggest ways to create it. As of July 1995, the group had made no significant progress. In addition to the above, it should be noted that the roots of the development right plan can be found in the introduction to the UN Charter, which it states "social progress and better living conditions with more freedom" (Shaygan; others, 2003: 52).

The Vienna declaration and the Action Plan of 52 June1993 describe the right to development in this way "A universal and inalienable right and an integral part of fundamental human rights". The declaration of the right to development also states this principle "An inalienable human right by which every human being and all people have the right to economic, social, cultural and political development in which all human rights and fundamental freedoms are fully realized, participate and cooperate and enjoy it. Human rights commission entitled "Human rights and unilateral coercive measures", explicit trade restrictions, blockade of transactions and freezing of assets lists as coercive measures which are considered human rights crimes (www.un.org/en/rights/index.shtml).

Article 2 of the declaration of the right to development recognizes this right as an individual right and introduces the person entitled and responsible for this right and declares that individuals have the right and responsibility to pursue this right; And all governments have the primary responsibility for providing, enforcing and enforcing this right. In this declaration, the right to development a collective right and yet is an individual.

In scientific terms, economic growth means an increase in production, while development does not mean that, rather the term development, in addition to increasing national production, refers to technical and organizational changes in how production works. Development represents continuous and comprehensive changes in the composition of production and resource allocation in different sectors of the country's economy. Economic growth is allegorically meant to increase height with weight gain, but development means increasing the body's capacity for learning, thinking, or coordination. Economic growth is necessary for development, but it does not mean development, there are many countries with high per capita economic growth they are considered as underdeveloped countries because of the low manpower efficiency. Hence economic development means that in addition to increasing production, working conditions have been created in the social and economic structure of society to ensure continued economic growth." (Masavat, Baba Amiri, Farhadi, 2016: 12).

Endowment can have a significant effect on growth and development. Such as the growth and development of service and social activities, production activities and agricultural activities, etc. "When it comes to the effect of endowments on economic independence and growth and development it never means that endowment alone can encompass all the various dimensions and angles of a nation's economy, so that the country's economy no longer needs financial benefits, rather, it means that the endowment as a huge financial investment can play a constructive and significant role and a large share in this direction. Nor does it mean that, contrary to the intentions and intentions of the endowments, we divert the endowment income from the main items of their expenditure which (for example) are mentioned in the endowment letters and use and consume them in the way of achieving economic independence and development growth. The truth is that the huge endowment capitals can be made like other capitals by observing all aspects of the endowment and the criteria of Sharia and the intentions 
and goals of the acquaintances in the process of production and service activities and get them out of recession and led from spending to mobility. In this way, it has been a great and significant help to the growth and development and economic and political independence of the country, the endowment funds should be increased day by day, which is definitely in the direction of the endowment's intentions." (Haeri, 2001: 531).

Also, the good tradition of endowment can help the government in solving economic problems. In this way, it reduces the government budget deficit by helping to create public services and goods and such a government is exempt from spending funds for the construction and management of schools or clinics, etc., which are built as endowments and it can spend that budget on other things. And this is how the people, along with the government, make society prosperous.

\section{Conclusion}

Endowment, with its special characteristics and qualities, exists exclusively in Islamic jurisprudence and Institutions like endowment have emerged before Islam and after Islam among other nations with almost similar functions, but none are like endowment. Endowment and Trust have been formed in different cultural backgrounds, therefore, the differences in the cultural, social and economic conditions of the formation of these two institutions have created fundamental differences in them. In creating endowment, the primary motive and goal is the intention of closeness and creating current charity, although jurists usually do not consider the intention of closeness as a condition of endowment and therefore, endowment can be created according to other motives such as altruism, leaving a memorial in one's name in the mortal world, and so on. Endowment as a component of sustainability in the Islamic system leads to the expansion of sustainable social capital. And any society with more social capital will certainly have a more stable economy. In the meantime, by generalizing the subject to the details, institutions are created, each of which in turn has economic stability, and in general, they solve the needs of the social network according to the components of sustainable development.

In general, endowment can be effective in achieving peace and human rights in two ways: 1. the spirit of independence and economic growth and development (based on Islamic norms) that will naturally lead to public welfare and the elimination and significant reduction of poverty and deprivation and its negative effects on society. 2. Most of the consumption items that far-sighted and benevolent endowments have considered throughout the history of endowment are related to public welfare, poverty alleviation and social justice.

Endowment removes property from the private property of individuals and causes the use of many people that this action opens many economic knots. It also creates cooperation and partnership in the community. The endowment has an important effect on the education of the country, as it helps a lot to improve the educational level of the country by constructing schools, mosques and libraries. The endowment culture institution allocates a large part of the endowment property to scientific, educational and cultural centers. Endowment also promotes justice, reduces class distance and eliminates poverty from society and also have many benefits for the government, as endowments help reduce government spending by providing social services to the people. The tradition of endowment provides the basic needs of the people such as job creation, construction of bridges, factories, orphanages, various things for the beauty of the urban space and leads to the realization of social welfare in society. Endowment can have a significant effect on the growth and development of productive and agricultural activities. The countless effects of endowments in the field of health cannot be ignored. Health issues are one of the essential needs of the people and the inalienable right of every individual in human society that the Endowments have provided these services through their benevolent deeds and they have been able to save the lives of many people. Because the more active the provision of health services in a community, public comfort and welfare will also be greater. 


\section{References}

Aminian Modarres, M. (2003). Endowment from the point of view of law and laws, Organization for the Study and Compilation of Islamic Sciences Books of Universities (Samat), Tehran.

Aminiya, A. (2010). The Right to Peace and the Performance of the United Nations, World Islamic Peace Assembly, (University Department).

Ayatollah, S. A., Mohammadi, A. R. Y. (2004). Eternal Savings Endowment, Mafakher, Tehran.

Bakai, M. H. (1998). Endowment Bibliography, first edition, Aswa edition, Qom, published by the cultural deputy of the organization and endowments and charitable affairs.

Cortight, D. (2008). Peace: A History of Movements and Ideas Oth Edition, Cambridge University Press.

Durant, W. (2001). History of Civilization, translated by Abolghasem Taheri, vol. 4, Scientific and Cultural Publishing Company.

Eghbali, A. (2010). "Endowment and a model for its economic evaluation", accounting Monthly, Vol. 130.

Fakhr, Al-M.. (2009). Explaining the Benefits, Vol. 2, by the efforts of Ayatollah Seyyed Mahmoud Shahroudi, first edition.

Haeri, Y., \& Mohammad, H. (2001). Endowment in Islamic jurisprudence and its role in the flourishing of Islamic economics, Astan Quds Razavi Research Foundation, Mashhad.

Hala investigator, Ja farban al-Hasan Abul-Qasim Najm al-Din. (1989). the useful shorthand in the jurisprudence of the Imamate, Harran, published by Mawsasah. ,3,

Hashemian, A. (2000). Cultural Developments in Iran during the Qajar Period and Dar alFonun School; Tehran: Sahab Institute of Geography and Cartography.

Masavat, S. E, Esmail Baba, A., \& Farhadi P. (2016). A Study of the Social Functions of Endowment in Improving Social Welfare, Proceedings of the First National Conference on Sustainable Charity (Study and Evaluation of Charity in Iran), Rahbari Ala Charity Foundation.

Mohtadin, M. (2007). Cultural, Political and Social Monthly of the Endowment and Charity Organization, February, p. 19.

Molaei, Y. ( 2002) "The Right to Development and the Universalization of Human Rights". Law Quarterly, 2, 90-99.

Mostofi, R. (1998). My biography: Social and administrative history of the Qajar period, fourth edition, Tehran: Zavar.

Riahisamani, N. (2012). How to endowment. Immortal Heritage Endowment Quarterly, 17, 6889.

Sadeghi Goldar, A. (2006). Introduction to Endowment Culture, Tehran, Saen Publications.

Saed, N. (2010). the Discourse of Just Peace, Basis and Meaning, World Assembly of Islamic Peace, Tehran.

Salimifar, M. (1991). A look at the endowment and its economic and social effects, Astan Quds Razavi Islamic Research Foundation, Mashhad.

Shah Hosseini, P. (2009). Geographical endowment of Tehran; Qajar and Pahlavi Periods. Geographical Research, 11(42), 127-145.

Shaygan, F. (2003). Strengthening International Cooperation in the Field of Human Rights, First Edition, Tehran, Gereish Publishing.

Spanta, A. (1967). History of Isfahan Endowments, Bija: Isfahan General Endowment Office.

Taghizadeh Ansari, M. (2008). Environmental Criminal Law, Tehran, Qoms Publishing.

Wali, Wahab, (1991) War and Peace. Journal of Culture, 14, 59-78. 